\title{
Paideusis
}

\section{Professional Development Schools: Schools for Developing a Profession (Linda Darling-Hammond (Ed.))}

\section{Michael J. B. Jackson}

Volume 9, Number 1, 1995

URI: https://id.erudit.org/iderudit/1073253ar

DOI: https://doi.org/10.7202/1073253ar

See table of contents

Publisher(s)

Canadian Philosophy of Education Society

ISSN

0838-4517 (print)

1916-0348 (digital)

Explore this journal

Cite this review

Jackson, M. (1995). Review of [Professional Development Schools: Schools for Developing a Profession (Linda Darling-Hammond (Ed.))]. Paideusis, 9(1),

28-32. https://doi.org/10.7202/1073253ar viewed online.

https://apropos.erudit.org/en/users/policy-on-use/ 
forms of patriotic and nationalistic education" (p. 181). Since anarchists of various kinds have long held similar positions, there is nothing new here. The list also speaks to the limitations of libertarian-anarchism. For example, under "Political Structure," Spring lists, "Create political structures that maximize the ability of all citizens to share equal political power in educational decisions," and "Eliminate federal and state control of the curriculum, teacher education, and methods of instruction." In both cases, the really difficult questions are how to achieve these structural changes and what is the role of education/pedagogy in achieving them.

Despite these weaknesses, Spring has succeeded in writing a student's first textbook in philosophy of education. It provides easy access to many of the more important philosophers of education in the Western canon while at the same time demonstrating the value of critical reflection. His argument about the liberating potential of education and the elements of a democratic education could be used to structure courses and readings at both the graduate and undergraduate levels. His efforts to relate the discussions of theory to the practices that result from them could also help to stimulate discussions in teacher education programmes. Even the limitations of the book provide ample fodder for exploration. Perhaps the greatest value of this book is that in addition to accomplishing these things, it stimulates questions about the "wheels in the head" that shape us all.

Reviewed by Timothy J. Stanley, Université d'Ottawa

Linda Darling-Hammond (Ed.), Professional Development Schools: Schools for Developing a Profession (Professional Development and Practice Series). New York and London: Teachers College Press, 1994.

The central task of the current reform movement in education is nothing less than building and transforming schools that are struggling to achieve democratic ideals. The purpose of the Professional Development and Practice Series is to contribute to this historic transformation by presenting a variety of descriptions of practice-oriented research .... As new organizational arrangements and collaborative relationships are being forged and studied, old enduring problems are being looked at in new ways that are leading us to fresh insights .... The writers in this series are attempting to involve us in a dialog about action, participation, and change based on the best evidence. (From the Series Editor, v.)

As one teacher asserted: "We want to be involved in teacher education, that's what the bottom line is .... I feel like it is so important to us to send out good teachers, not just teachers, but good teachers ... . We have seen weak teachers .... If we are going to get the respect that is due our profession, we have got to take charge and build our profession up" (p. 187).

The nine chapters are the work of fourteen contributors; three are explicitly identified as teachers, three others as former teachers; most were participants in the projects they describe (p. 49). With the proliferation of "schooluniversity collaborations ... that call themselves PDSs [professional development schools]" (p. 2) and now, in Quebec, required contracts for the supervision 
of practice teaching, clarification and synthesis would seem timely. This book examines (1) "how the PDS concept has evolved, how partnerships have been forged, what models are being developed, and what barriers and obstacles have been encountered and overcome" from the perspective of "teaching's transition from a bureaucratized occupation to a profession;" (2) "case studies of seven different PDS models in very different communities," one from two different perspectives and usually with a methodological note; and (3) the requirements for collaboration (pp. 2-3). The first (by Darling-Hammond) and last (by Sharon Robinson and Darling-Hammond) should be of special interest to readers of this journal. Unfortunately, that interest is limited.

But in discussions of practice, the experiences of participants are often revealing and their observations and comments insightful. In the spirit of "the best evidence," the case studies in the middle seven chapters are invaluable not only to guide other practice but in sense-making. Here, even if the enthusiasm occasionally sounds self-congratulatory, the book does not disappoint in that readers, especially those attracted to Goodlad's ideas, come away well informed about practices, experiments and the thoughts of participants, and armed with telling examples and the odd horror story. Ad hoc, chance, risk taking, personalities and earlier relationships occur more than once as explanations of success and occasionally failure; projects are often small, involving 12-26 selected student teachers; and "demoralizing" is applied less to time and money than to understanding, power, and appreciation.

Points to ponder include:

- the future for faculties of education but also for teacher education if faculties ignore, or are pushed to downplay, their mandate to prepare teachers and the status and career prospects of those involved (pp. 43, 69, 187-188);

- the unequal status of teachers for whom promotion often means leaving teaching (p. 122), who may be required to take training in practice-teaching supervision to participate (p. 99 , but also in Quebec; cf. p. 118ff.), who like student teachers who "'[m]ake. public what is happening in [their] classrooms" while university faculty "make similar declarations" (p. 173), and who come to the university as students or, at best, sessional instructors or clinical associates while faculty and graduate students go to schools to advise, direct, and do research on them (pp. 59, 90, 95, 178, 186);

- faculty and university mores and disagreements about the needs of future teachers (pp. 188-190, 198), demands on teachers' time (p. 193), and risks to innovations during budgets cuts (p. 179);

- differing views of PDS and professionalism (p. 192, 198) and the variety of school reform projects that have been teamed with PDS (pp. 70, 105), some seemingly at cross-purposes (pp. 87-88);

- the inconsistency of reform projects with state or local requirements and expectations for curricula, student achievement, and teacher certification (as in Kentucky and South Carolina; pp. 87, 93, 184-185, 194, 196); 
- the simple contagion of enthusiasm but also the voices of teachers not heard in the enthusiasm (pp. 65, 83-84).

I wonder, too, about the problems created for those who enter schools identified as "student teachers" or "mentors." But, thanks to books like this, it can at least no longer be said that "What is happening ... are a series of private epiphanies about conceptions of knowledge and the appropriate role of school and university faculty ... there is no public discourse about what is happening" (p. 46).

Right from Judith Lanier's "Foreword," I found a tension behind the "inter-related purposes" of PDSs as "good places for preparing future teachers" and "places for responsible, enduring innovation in education" ( $p$. ix). To be sure, there is immediate reference to "the good practice and policy the profession needs to improve learning for young students" that can be expected to result and later to "the common goal of developing and supporting professional teaching practice" (p. 205) and "a sense of shared vision" (p. 209), but Dewey said as much for his laboratory school consciously modelled on the scientific research lab. It risks being a platitude. My concerns are five.

First, the interests of more than the school and the university should be considered for we have known the reign of the professional expert in education (cf. p. 93). Second, the interests of even these two parties are "different, if not antagonistic" (p. 203), yet they overlap: collaboration and professional develop-
ment require changes in curriculum, pedagogy, and school organization (pp204-207). Perhaps we should add "and vice-versa." Third, resolution of these differences by further collaborative processes (p. 207) exemplified in a new school with "fiber-optic and satellite communication ... technological applications ... . conference rooms ... a research center . . . computers . . . desk-top publishing, and access to databases" (p. 208) and "clinical instructors ... co-teaching the first year curriculum with university faculty" (p. 209) not apparently faculty teaching elementary grades!-risks missing the issue. The language is perhaps revealing: "Collaborations ... may not look like the appropriate work of the organization .... Institutional leaders can assist the effort by giving legitimacy to this work and providing support . . . ." (p. 214; italics added). The ten characteristics of successful collaboration discussed in the final chapter are drawn from systems thinking and the literature on organizational change and learning organizations: they include shared goals, information, and decision making; mutual respect; clear, manageable tasks and the time to realize them; and various kinds of support. Fourth and most basic, as in practice teaching, the first claim on teachers' loyalties must remain the quality of the learning experiences and classroom life of their students, especially in the face of acknowledged "fads and self-proclaimed experts" (p. ix) and practices "often developed and implemented without regard to professional knowledge or the needs of clients" (p. 4). At worst, co-operating teachers "reteach" when the student teacher has left.

In part, teachers felt torn between opportunities for professional development and their sense of responsibility to classroom teaching .... how the PSPDC activities connected to "what I really do in the classroom." . . . being away from their classrooms too much ... [and] what they perceived as their major role-teaching middle grade students. (p.67; cf. pp. 108ff., 115-116, 171ff) 
Fifth, in our enthusiasm, we risk pretending to be all things to all people: prospective, beginning, and veteran teachers, teacher leaders, university educators, and researchers (cf. p. 1)-perhaps even students, parents, and a reformed community.

Darling-Hammond, however, believes that, in the face of our enormous expectations for schools, "the PDS-developed at the intersection of preservice education and inservice teaching-is a critical linchpin in developing teachers who can create learner- and learning-centered schools" (p. 6). It facilitates particularly the important but "unconventional" practices of collaboration, mentoring, and consultation in a collegial and co-operative environment, changing the whole school atmosphere (and often structures, and often reaching beyond the school) - "the fundamental relationships between and among students and teachers, the conceptualizations of what it means to know and to learn [and to teach], and the obligations that organizations have to those who work and leam in them" (p. 10)-not just the experiences of beginning teachers. And the case studies support these observations. Acknowledged exceptions (for example, pp. 143-144, 147-148) suggest a need to respect teachers' and student teachers' individuality just as individual attention to students provides "means to increase academic expectations for [most] youngsters without simultaneously increasing individual frustrations" (p. 150; compare with p. 181). With these reflective practices came success and its recognition, learning, changed classroom practices, new roles for a co-operating teacher who is no longer "a selfconscious mentor" (p. 13), new conceptions of knowledge, and "a teamteaching structure that contributes to the professional development of university faculty" (p. 12), and the reform of university programmes. In short, she sees a new professionalism based in "extensions of the constructivist understanding of knowledge that teachers and teacher educators have appreciated on behalf of children, and are just now beginning to extend to themselves and the knowledge base for their own work" (p. 16).

There is an index but it appears top-heavy with proper names; though mentioned in passing in the text, laboratory schools, clinical schools, and key schools are not to be found. Perhaps because of an interest in the "second wave" (p. 2) of school reform reports beginning with the Holmes Group in 1986, Dewey, too, though mentioned (once only, I think) in the text, is not to be found. Few foundations scholars are. Yet, we read:

"Who owns the knowledge?" "Whose knowledge counts?" and "What is our knowledge?" are the more fundamental questions of school-university collaboration that emerge and must be grappled with as PDSs-and the profession of teaching-strive to grow up. (p. 3)

Answering the questions that underlie PDS planning opens a Pandora's box of potentially radical rethinking: How do we envision the school as a community of learners? What do we want children to know? What do we want prospective teachers to know? How do we want teachers to be, to act? What opportunities do we want for teachers as lifelong learners? What do all of these things mean for the ways in which we structure teaching and learning opportunities ....? (p. 16)

Perhaps what is most striking . . . is the widespread use of a common language with which members talked about the activities of teaching, learning, and the process of reform. However, the common language of the 
school was not necessarily shared by the other half of the partnership-the university. (p. 71)

And with language went assumptions, beliefs, agendas and policies. The vision is exciting, but despite important distrust, misunderstandings, problems of communication, and conflicting agendas of schools, boards, and universities the questions are not all practical.

Reviewed by Michael J. B. Jackson, Montreal 